九州大学学術情報リポジトリ

Kyushu University Institutional Repository

Comparative Studies on Fatty Acid Composition of the Whole-Cell and Outer Membrane in Brazilian Strains of Ralstonia solanacearum

Melo, Maria Salete de

Laboratory of Plant Pathology, Faculty of Agriculture, Kyushu University

Furuya, Naruto

Laboratory of Plant Pathology, Faculty of Agriculture, Kyushu University

Matsumoto, Masaru

Laboratory of Plant Pathology, Faculty of Agriculture, Kyushu University

Matsuyama, Nobuaki

Laboratory of Plant Pathology, Faculty of Agriculture, Kyushu University

https://doi.org/10.5109/24301

出版情報 : 九州大学大学院農学研究院紀要. 44 (1/2)，pp.17-23，1999-11. Kyushu University バージョン：

権利関係: 
J. Fac. Agr., Kyushu Univ, $44(1 \cdot 2), 17-23(1999)$

\title{
Comparative Studies on Fatty Acid Composition of the Whole- Cell and Outer Membrane in Brazilian Strains of Ralstonia solanacearum
}

\author{
Maria Salete de Melo, Naruto Furuya, Masaru Matsumoto* \\ and Nobuaki Matsuyama \\ Laboratory of Plant Pathology, Faculty of Agriculture, Kyushu IJniversity 46-01, \\ Fukuoka 812-8581, Japan \\ (Receined June 22, 1999 and accepted August 24, 1999)
}

\begin{abstract}
The fatty acid analysis of Brazilian strains of Ralstonia solanacearum was conducled by gas-liquid chromatography (GLC). Using 29 strains from Brazil, profiles of the whole-cell fatty acid methyl esters (FAME) were compared. Qualitative and quantitative differences in the profiles of FAMEs were not observed among thc strains.

When the fatty acid analysis of the bacterial ccllular membrane was conducted, striking outcome was obtained. In particular, the ratios of the amount of 2-hydroxypalmitic: acid(16:1 $2-\mathrm{OH}$ ) and an unidentifited fatty acid (Rt 16.4) varicd greatly depending on original host plants and biovars. The fatty acid profiles of the strains from pepper (biovars 2 and 3), banana (biovar 1) and cucalyptus (biovar 1) were clearly different from those of the strains isolated from other plants. These results indicate that fatty acid profiles of the outer-membrarle might reflect the tifferences of the host plants from which the isolates were oblained. Baclerial outer-membrane fatty acid profiles will be useful as a benchmark for the classification and identificalion of $R$. solanacearum at subspecies level.
\end{abstract}

\section{INTRODUCTION}

Intraspecific grouping of Ralstonia solanacearum (Yabuuchi et al., 1995) (syn. Pseudomonas solanacearum) remains a complex subject (Okabe and Goto, 1961). Arrangements based on host specificity, which resulted in five races (Buddenhagen and Kelman, 1964, Buddenhagen el al., 1962, He et al., 1983), did not coincide with grouping based on physiological criteria (Hayward, 1964, He et al., 1983), which lead to the recognition of five biovars. Further detailed phenotypic, chemotaxonomic and genetic studies are required to clarify the taxonomic structure of $R$. solanacearum.

To supply additional data which may help to understand the complex species of $R$. solanacearum, we analyzed the whole-cell and the outer-membrane fatty acid methyl esters (FAMEs) of Brazilian strains of this bacterium by gas-liquid chromatography.

\section{MATERIALS AND METHODS}

\section{Bacterial isolates and culture}

Twenty-nine Brazilian strains of Ralstonia solanacearum and type strain ATCC11696 and type strains of $R$. pickettii ATCC27511, Erwinia carotovora subsp.

*Present address: Institute of Tropical Agriculture, Kyushu University, Fukuoka 812-8581, Japan 
carotovora ATCC33260, E. c. subsp. atroseptica ATCC43762, Xanthomonas campestris pv. campestris ATCC33913, Burkholderia (Yabuuchi et al., 1992) (syn: Pseudomonas) caryophylli ATCC25418, B. gladioli pv. gladioli ATCC10248 and Agrobacterium tumefaciens ATCC23308 maintained in author's laboratory were used in this study. Each bacterial strain of $R$. solanacearum was pre-cultured on the plate of TTC medium (peptone $10 \mathrm{~g}$, casein hydrolysate (Difco) $1 \mathrm{~g}$, glucose $5 \mathrm{~g}$, agar $17 \mathrm{~g}$, triphenyl tetrazolium chloride (1\% solution) $5 \mathrm{ml}$, distilled water 1 liter) at $30^{\circ} \mathrm{C}$ for $48 \mathrm{hr}$ for selecting virulent colonies. Typical virulent colonies were isolated and cultured in $200 \mathrm{ml}$ of 523 medium (Kado and Heskett, 1970) in Sakaguchi flask by shaking at $30^{\circ} \mathrm{C}$ for $24 \mathrm{hr}$. Type strains other than $R$. solanacearum were pre-cultured on the plates of potato semi-synthetic agar (PSA) medium (Wakimoto, 1955) at $30^{\circ} \mathrm{C}$ for $24 \mathrm{hr}$ and then cultured in 523 broth at $30^{\circ} \mathrm{C}$ for $24 \mathrm{hr}$.

\section{Preparation of the samples}

The bacterial cells were harvested by centrifugation $(3,500 \times g, 30 \mathrm{~min})$, resuspended in $0.85 \% \mathrm{NaCl}$ solution and centrifuged. A part of the pellet was lyophilized and stored as the whole-cell sample. Five grams (f.wt) of the precipitated cells was resuspended in $100 \mathrm{ml}$ of $0.2 \mathrm{M} \mathrm{LiCl}$ solution and shaken (156 strokes/min) at $45^{\circ} \mathrm{C}$ for $2.5 \mathrm{hr}$ with glass beads ( $1 \mathrm{~mm}$ in diameter). The supernatant obtained by centrifugation $(5,000 \times g$ : $20 \mathrm{~min}$ ) was recentrifuged at, $30,000 \times g$ for $40 \mathrm{~min}$ to remove large membranous materials. The resulting supernatant was then centrifuged at $100,000 \times \mathrm{g}$ for $2 \mathrm{hr}$ and the pellet was washed once with distilled water under the same centrifugal conditions. All of the centrifugation was conducted at $4{ }^{\circ} \mathrm{C}$. The bacterial outer membrane obtained was lyophilized and stored in a desiccator.

\section{Preparation of fatty acids}

Five milligrams of the lyophilized whole-cell or outer membrane was methylated with $2 \mathrm{mi}$ of $5 \% \mathrm{HCl}-$ methanol at $100^{\circ} \mathrm{C}$ for $3 \mathrm{hr}$ in a sealed glass tube to obtain fatty acid methyl ester (FAME) derivatives. After methanolysis, one $\mathrm{ml}$ of water was added and the FAMEs were extracted with petroleum ether by shaking. The solvent phase was washed with equal volume of distilled water to remove $\mathrm{HCl}$ and dehydrated by mixing wilh $0.5 \mathrm{mig}$ of anhydrous sodium sulfate. The organic phase was concentrated by nitrogen gas blowing. Samples were stored at $-20^{\circ} \mathrm{C}$.

\section{Preparation of fatty acids}

FAMEs were analyzed by a gas-liquid chromatograph (Shimazu GC 17A) equipped with a FID detector and $0.25 \mathrm{~mm} \times 50 \mathrm{~m}$ HR-SS-10 capillary column. The column and injection-port temperatures were maintained at $180^{\circ} \mathrm{C}$ and $250^{\circ} \mathrm{C}$, respectively. The pressure of nitrogen gas was $95 \mathrm{Kpa}$. Each FAME was identified by comparing its retention time with known samples. Peak area was calculated automatically and expressed as percentage composition. The analysis was repeated three times for each strain. Average values of the composition of fatty acids were used to differentiate the strains of $R$. solanacearum. 


\section{RESULTS AND DISCUSSION}

The results ir Table 1 show that various species of phytopathogenic bacteria have unique FAMEs profiles. All of the strains contained myristic (14:0), palmitic (16:0) and palmitoleic acids (16:1 cis 9 ) and these acids were often major. Striking differences in the composition of fatty acids were observed among type strains of Ralstonia solanacearum, Erwinia carotovora subsp. atroseptica, E. c. subsp. carotovora, Agrobacterium tumefaciens and Xanthomonas campestris pv. campestris. Moreover, $R$. solanacearum was differentiated from Burkholderia caryophylli and B. gladioli pv. gladioli, which belong to ribosomal RNA group II by DNA-DNA hybridization studies by Palleroni et al. (1973), on the basis of fatty acid compositions of oleic (18:1) and two kinds of unidentified fatty acids (Rt 8.9 and Rt 10.9). Although $R$. pickettii is very closely related with $R$. solanacearum in bacterial properties, these two species were readily differentiated by the presence or absence of oleic (18:1), 2-hydroxypalmitic (16:1 2-OH) and three kinds of unidentified fatty acids (Rt 8.9, Rt 11.2 and Rt 16.4).

Eight kinds of fatty acid were identified and quantified in Brazilian strains of $R$. solanacearum. They were myristic (14:0), palmitic (16:0), palmitoleic (16:1 cis 9), vaccenic (18:1 cis 11), 2-hydroxypalntitic (16:0 2-OH) and three kinds of undentified fatty acids (Rt 9.7, Rt 10.9 and Rt 16.4).

As can be seen in Table 2, all of Brazilian strains had very similar profiles of whole-cell FAMEs and no significant differences were observed. In the case of outer membrane FAMEs indicated in Table 3, the unidentified fatty acid (Rt 16.4) was not found excepting eucalyptus strains. Although striking differences were not detectable within Brazilian strains, small but distinct differences were observed among the strains from different hosts and biovars. 2-hydroxypalmitic (16:1 2-OH) acid could not be detected in pepper strains of biovars 2 and 3 . On the other hand, banana strain had a higher percentage of this fatty acid. The unidentified fatty acid (Rt 9.7) was detected at a high concentration in eggplant strains of biovar 2, cucumber strains of biovar 1 , and pepper strains of biovars 1 and 3. These results might indicate that the FAME profiles of outer membrane related partly with the host or biovar. Further studies with larger numbers of strains and analysis under different cultural conditions will be required to determine whether $\bar{k}$. solanacearum can be differentiated at biovar or race level by their fatty acid profiles.

\section{REFERENCES}

Buddenhagen, I. W. and A. Kelmar 1964 Biological and physiological aspects of bacterial wilt caused by Pseudomonas solanacearum. Ann. Rev. Phytopathol., 2: 203-230

Buddenhagen, I. W., L. Sequeira and A. Kelman 1962 Designation of races in Pseudomonas solanacearum. (Abstr.) Phytopathology, 52: 726

Hayward, A. C. 1964 Characteristics of Pseudomonas solanacearum. J. Appl. Bacteriol., 27: 265-277

He, L. Y., L. Sequeira and A. Kelman 1983 Characteristies of strains of Pseudomonas solanaceamum from China. Plant Dis, 67: 1357-1361

Kado, C. I. and M. G. Heskett 1970 Selective media for isolation of Agrobacterium, Corynebacterium, Emwinia, Pseudomonas and Xanthomonas. Phytopathology, 60: 969-976

Okabe, N. and M. Goto 1961 Studies on Pseudomonas solanacearum. XI, Pathotypes in Japana. Shizuoka Univ. Fac. Agr. Rept., 11: 25-42 
Table 1. Percentage composition of total cellular fatty acids in various type strains of phytopathogenic bacteria.

\begin{tabular}{|c|c|c|c|c|c|c|c|c|c|c|c|c|c|c|c|c|}
\hline \multirow[b]{2}{*}{ Type strain } & \multicolumn{13}{|c|}{ Percentiage composilion of fatty acid } & \multirow[b]{2}{*}{$\begin{array}{c}16: \overline{1} \\
2-\mathrm{OH}\end{array}$} & \multirow[b]{2}{*}{$\begin{array}{c}\mathrm{Rt} \\
16.4\end{array}$} & \multirow[b]{2}{*}{$\begin{array}{c}\mathrm{Rt} \\
20.4\end{array}$} \\
\hline & $10: 0$ & $12: 0$ & 14:0 & $16: 0$ & $\begin{array}{l}16: 1 \\
c i s 9\end{array}$ & $\begin{array}{c}12: 0 \\
3 \mathrm{OH}\end{array}$ & $\begin{array}{l}R^{2} t^{* i} \\
8.9\end{array}$ & $\begin{array}{l}\text { Rt } \\
9.7\end{array}$ & $18: 1$ & $\begin{array}{c}\mathrm{Rl} \\
10.9\end{array}$ & $\begin{array}{c}\text { Rt. } \\
11.2\end{array}$ & $\begin{array}{c}18: 1 \\
\text { cis } 11\end{array}$ & $20: 0$ & & & \\
\hline E. c. subsp. atroseptica & $0.0^{\mathrm{b}}$ & 6.97 & 4.56 & 33.58 & 21.94 & 0.00 & 2.89 & 0.00 & 5.03 & 0.00 & 11.97 & 0.00 & 13.03 & 0.00 & 0.00 & 0.00 \\
\hline E. c. subsp. carotowora & 0.00 & 19.17 & 2.63 & 19.05 & 20.41 & 0.00 & 0.59 & 0.00 & 4.93 & 0.00 & 2.45 & 0.00 & 30.73 & 0.00 & 0.00 & 0.00 \\
\hline$X . c$. pv. campestris & 17.70 & 0.00 & 10.09 & 15.18 & 32.47 & 14.94 & 7.23 & 0.00 & 0.00 & 0.00 & 0.00 & 2.35 & 0.00 & 0.00 & 0.00 & 0.00 \\
\hline B. caryophylli & 0.00 & 0.00 & 5.03 & 22.45 & 10.61 & 0.00 & 3.06 & 0.00 & 14.79 & 0.00 & 8.20 & 18.03 & 0.00 & 4.13 & 2.14 & 11.51 \\
\hline B. g. pv. gladioli & 0.00 & 0.00 & 6.59 & 19.34 & 14.07 & 0.00 & 0.88 & 0.00 & 10.41 & 0.00 & 7.46 & 20.36 & 0.00 & 3.34 & 4.42 & 13.07 \\
\hline A. tumefaciens & 0.00 & 4.84 & 1.59 & 9.99 & 10.23 & 0.00 & 0.00 & 0.00 & 57.44 & 0.00 & 0.00 & 8.84 & 0.00 & 0.00 & 0.00 & 7.04 \\
\hline R. pickettii & 0.00 & 0.00 & 7.81 & 15.54 & 32.40 & 0.00 & 3.89 & 0.00 & 6.50 & 0.00 & 1.86 & 31.96 & 0.00 & 0.00 & 0.00 & 0.00 \\
\hline R. solanacearum & 0.00 & 0.00 & 11.68 & 20.18 & 10.15 & 0.00 & 0.00 & 4.96 & 0.00 & 7.38 & 0.00 & 23.82 & 0.00 & 19.10 & 2.69 & 0.00 \\
\hline
\end{tabular}

a) Rt means retention time and $\mathrm{Rt} 8.9$, Rt 9.7 , Rt 10.9, Rt 11.2 , Rt 16.4 and Rt 20.4 are unidentified fatty acids.

b) Fally acids in each strais are expressed as a percentage of total cellular fatty acid compositions. Fatty acids were identified by their retention times on the gas-liquid chromatogram. 
Table 2. Percentage composition of fatty acids of whole-cell in Brazilian strains of Ralstonia solanacearum.

\begin{tabular}{|c|c|c|c|c|c|c|c|c|c|c|}
\hline \multirow[b]{2}{*}{ Strain } & \multirow[b]{2}{*}{ Host } & \multirow[b]{2}{*}{ Biovar } & \multicolumn{8}{|c|}{ Percentage composition of fatty acid } \\
\hline & & & 14:0 & $16: 0$ & $\begin{array}{l}16: 1 \\
\text { cis } 9\end{array}$ & $\begin{array}{l}\mathrm{Rt}^{* j} \\
9.7\end{array}$ & $\begin{array}{c}\mathrm{Rt} \\
10.9\end{array}$ & $\begin{array}{c}18: 1 \\
\text { cis } 11\end{array}$ & $\begin{array}{c}16: 1 \\
2-O H\end{array}$ & $\begin{array}{c}\mathrm{Rl} \\
16.4^{\text {o) }}\end{array}$ \\
\hline 578 & Potato & 1 & $11.0^{b x}$ & 24.65 & 20.53 & 10.45 & 6.46 & 14.60 & 2.84 & 9.41 \\
\hline 1005 & Potato & 1 & 9.40 & 31.94 & 14.46 & 9.77 & 8.73 & 17.18 & 3.93 & 4.55 \\
\hline 98 & Potato & 2 & 9.10 & 19.17 & 34.12 & 8.64 & 4.26 & 18.96 & 0.85 & 4.87 \\
\hline 964 & Potato & 2 & 9.74 & 20.20 & 27.15 & 8.69 & 4.29 & 22.39 & 3.87 & 3.63 \\
\hline 799 & Potato & 2 & 11.16 & 31.42 & 25.69 & 12.69 & 4.65 & 9.96 & 2.31 & 2.08 \\
\hline 19 & Tomato & 1 & 17.09 & 24.86 & 22.83 & 7.98 & 6.93 & 14.28 & 3.84 & 2.15 \\
\hline 76 & Tomato & 1 & 9.86 & 33.72 & 29.20 & 15.37 & 2.79 & 6.41 & 1.07 & 1.53 \\
\hline 1033 & Tomato & 1 & 11.08 & 24.33 & 19.02 & 7.45 & 11.05 & 18.69 & 2.73 & 5.61 \\
\hline 855 & Tomato & 2 & 12.73 & 25.13 & 27.79 & 14.75 & 6.69 & 8.42 & 2.71 & 1.74 \\
\hline 49 & Tomato & 3 & 12.93 & 23.19 & 30.28 & 11.32 & 2.90 & 10.96 & 2.70 & 5.67 \\
\hline 630 & Tomato & 3 & 7.17 & 30.44 & 28.37 & 17.88 & 3.52 & 8.22 & 1.68 & 2.68 \\
\hline 628 & Tomato & 3 & 7.83 & 38.25 & 27.40 & 18.71 & 3.34 & 3.45 & 0.77 & 0.21 \\
\hline 1104 & Tomato & 3 & 6.88 & 25.81 & 17.00 & 9.02 & 13.15 & 20.09 & 2.73 & 5.28 \\
\hline 127 & Pepper & 1 & 11.67 & 37.65 & 24.12 & 15.96 & 3.33 & 4.66 & 1.30 & 1.27 \\
\hline 162 & Pepper & 2 & 14.08 & 26.61 & 27.09 & 12.47 & ว..44 & 9.83 & 0.85 & 3.58 \\
\hline 7 & Pepper & 2 & 9.71 & 23.29 & 23.71 & 14.35 & 2.42 & 10.40 & 11.98 & 4.10 \\
\hline 20 & Pepper & 3 & 9.60 & 30.92 & 31.04 & 12.69 & 3.88 & 9.04 & 0.53 & 2.24 \\
\hline 582 & Pepper & 3 & 9.70 & 23.71 & 32.32 & 14.34 & 3.54 & 12.46 & 1.50 & 2.39 \\
\hline 73 & Banana & 1 & 7.08 & 29.72 & 28.73 & 12.14 & 3.56 & 15.25 & 2.06 & 1.40 \\
\hline 656 & Cucumber & 1 & 10.80 & 26.65 & 27.65 & 7.62 & 4.59 & 6.18 & 14.87 & 1.61 \\
\hline 129 & Cucumber & 1 & 9.29 & 24.31 & 29.42 & 9.31 & 4.12 & 19.20 & 3.00 & 1.30 \\
\hline 574 & Eucalyptus & 1 & 12.20 & 25.86 & 31.10 & 8.88 & 5.67 & 10.53 & 4.36 & 1.36 \\
\hline 579 & Eucalyptus & 1 & 12.96 & 22.66 & 28.18 & 7.87 & 5.72 & 16.91 & 2.08 & 3.58 \\
\hline 87 & Eggplant & 2 & 11.58 & 22.68 & 23.19 & 8.17 & 6.19 & 19.27 & 5.48 & 3.42 \\
\hline 79 & Eggplant & 2 & 10.85 & 20.84 & 26.52 & 8.15 & 5.45 & 21.26 & 3.22 & 3.68 \\
\hline 71 & Eggplant & 2 & 18.12 & 25.69 & 28.62 & 10.34 & 5.99 & 8.17 & 1.22 & 1.82 \\
\hline อั6 & Eggplant & 3 & 14.32 & 26.53 & 30.73 & 10.31 & 5.22 & 9.83 & 0.61 & 2.41 \\
\hline 51 & Eggplant & 3 & 7.57 & 24.61 & 34.60 & 14.67 & 3.51 & 11.03 & 0.86 & 3.12 \\
\hline 47 & Solanum gilo & 3 & 16.36 & 33.75 & 11.85 & 12.59 & 3.90 & 11.16 & 6.20 & 4.15 \\
\hline
\end{tabular}

a) Rt means retention time and Rt 9.7, Rt 10.9 and Rt 16.4 are unidentified fatty acids.

b) Fatty acids in each strain are expressed as a percentage of total outer membrane fatty acid compositions. Fatty acids were identified by their retention times on the gas-liquid chromatogram. 
Table 3. P'ercentage composition of fatty acid of bacterial outer membrane in Brazilian strains of Ralstonia solanacearum.

\begin{tabular}{|c|c|c|c|c|c|c|c|c|c|c|}
\hline \multirow[b]{2}{*}{ Strain } & \multirow[b]{2}{*}{ Host } & \multirow[b]{2}{*}{ Biovar } & \multicolumn{8}{|c|}{ Percentage composition of fatty acid } \\
\hline & & & $14: 0$ & $16: 0$ & $\begin{array}{l}16: 1 \\
\text { cis } 9 \\
\end{array}$ & $\begin{array}{l}R(t) \\
9.7\end{array}$ & $\begin{array}{c}\mathrm{Rt} \\
10.9\end{array}$ & $\begin{array}{c}18: 1 \\
\text { cis } 11\end{array}$ & $\begin{array}{c}16: 1 \\
2-\mathrm{OH}\end{array}$ & $\begin{array}{c}\text { Rt } \\
16.4 \\
\end{array}$ \\
\hline 578 & Potato & 1 & $20.62^{\mathrm{b}}$ & 24.08 & 11.87 & 7.63 & 3.21 & 30.19 & 2.37 & 0.00 \\
\hline 1005 & Potato & 1 & 17.59 & 13.07 & 22.18 & 2.34 & 1.79 & 42.18 & 0.83 & 0.00 \\
\hline 98 & Potato & 2 & 12.80 & 22.43 & 19.18 & 10.10 & 2.72 & 27.33 & 5.40 & 0.00 \\
\hline 964 & Potato & 2 & 16.26 & 14.37 & 25.63 & 1.92 & 2.03 & 38.53 & 1.23 & 0.00 \\
\hline 799 & Potato & 2 & 18.15 & 17.32 & 26.83 & 3.44 & 2.15 & 32.07 & 0.00 & 0.00 \\
\hline 19 & Tomato & 1 & 19.59 & 11.92 & 20.96 & 2.03 & 1.74 & 42.05 & 1.68 & 0.00 \\
\hline 76 & Tomato & 1 & 15.43 & 34.09 & 18.48 & 0.04 & 5.82 & 26.09 & 0.02 & 0.00 \\
\hline 1033 & Tomato & 1 & 15.11 & 17.42 & 23.47 & 3.85 & 3.07 & 37.04 & 0.00 & 0.00 \\
\hline 855 & Tomato & 2 & 15.83 & 14.49 & 13.33 & 5.55 & 2.68 & 44.79 & 3.30 & 0.00 \\
\hline 49 & Tomato & 3 & 20.50 & 12.04 & 38.20 & 1.12 & 1.40 & 22.07 & 4.27 & 0.00 \\
\hline 630 & Tomato & 3 & 14.44 & 9.76 & 26.43 & 5.01 & 1.11 & 42.29 & 0.93 & 0.00 \\
\hline 628 & Tomato & 3 & 12.53 & 11.84 & 27.58 & 5.88 & 0.72 & 41.42 & 0.00 & 0.00 \\
\hline 1104 & Tomato & 3 & 17.57 & 16.24 & 22.90 & 0.00 & 2.05 & 38.68 & 2.54 & 0.00 \\
\hline 127 & Pepper & 1 & 14.32 & 23.33 & 16.13 & 12.37 & 2.71 & 30.32 & 0.79 & 0.00 \\
\hline 162 & Pepper & 2 & 22.13 & 18.56 & 37.02 & 1.06 & 0.87 & 20.34 & 0.00 & 0.00 \\
\hline 7 & Pepper & 2 & 22.60 & 11.53 & 4.35 & 1.67 & 15.20 & 44.62 & 0.00 & 0.00 \\
\hline 20 & Pepper & 3 & 15.11 & 16.57 & 19.25 & 14.13 & 0.82 & 34.10 & 0.00 & 0.00 \\
\hline 582 & Pepper & 3 & 12.99 & 18,65 & 17.98 & 15.95 & 2.68 & 31.72 & 0.00 & 0.00 \\
\hline 73 & Banana & 1 & 22.23 & 16.67 & 23.89 & 4.01 & 1.98 & 18.81 & 12.39 & 0.00 \\
\hline 656 & Cucumber & 1 & 9.19 & 27.77 & 27.76 & 13.07 & 1.86 & 17.97 & 2.35 & 0.00 \\
\hline 129 & Cucurnber & 1 & 14.18 & 24.70 & 19.56 & 16.59 & 3.79 & 21.14 & 0.01 & 0.00 \\
\hline 574 & Eucalyptus & 1 & 18.42 & 11.67 & 31.89 & 0.18 & 0.60 & 34.62 & 1.28 & 1.29 \\
\hline 579 & Eucalyptus & 1 & 11.35 & 13.21 & 19.66 & 7.37 & 1.35 & 46.11 & 0.80 & 0.12 \\
\hline 87 & Eggplant & 2 & 11.98 & 28.83 & 16.14 & 16.72 & 4.20 & 21.40 & 0.69 & 0.00 \\
\hline 79 & Eggplant & 2 & 15.15 & 20.06 & 31.38 & 9.45 & 1.95 & 21.98 & 0.00 & 0.00 \\
\hline 71 & Eggplant & 2 & 10.94 & 18.75 & 19.17 & 12.87 & 3.32 & 33.91 & 1.01 & 0.00 \\
\hline 56 & Eggplant & 3 & 20.90 & 16.09 & 32.95 & 1.49 & 1.19 & 27.35 & 0.00 & 0.00 \\
\hline 51 & Eggplant & 3 & 15.35 & 14.83 & 23.95 & 4.80 & 1.29 & 37.45 & 2.30 & 0.00 \\
\hline 47 & Solanum gilo & 3 & 16.33 & 14.31 & 26.52 & 4.47 & 1.76 & 35.97 & 0.60 & 0.00 \\
\hline
\end{tabular}

a) Rt means retention time and Rt 9.7 , Rt 10.9 and Rt 16.4 are unidentified fatty acids.

b) Fatty acids in each strain are expressed as a percentage of total outer membrane fatty acid compositions. Fatty acids were identified by their retention times on the gas-liquid chromatogram. 
Palleroni, N. J., R. Kunisawa, R. Contopoulou and M. Doudoroff 1973 Nucleic acid homologies in the genus Pseudomonas. Int. J. System. Bact., 23: 333-379

Wakimoto, S. 1955 Studies on the multiplication of OP1 phage (Xanthomonas oryzae bacteriophage) 1. One-step growth experiment under various conditions. Sci. Bull. Fac. Agr., Kyushu Lniv., 15: $151-160$

Yabuuchi, E., Y. Kosako, H. Oyaizu, 1. Yano, H. Hotta, Y. Hashimoto, T. Ezaki and M. Arakawa 1992 Proposal of Burkholderia gen. nov. and transfer to seven species of the genus Pseudomonas homology group II to the new genus, with the type species Burkholderia cepacia (Palleroni and Holmes 1981) comb. nov. Microbiol. Immunol., 36: 1251-1275

Yabuuchi, E., Y. Kosako, I. Yano, H. Hotta and Y. Nishiuchi 1995 Transfer of two Burkholderia and an Alcaligenes species to Ralstonia gen. nov.: proposal of Ralstonia pickettii (Ralston, Palleroni and Doudoroff 1973) comb. nov., Ralstonia solanacearum (Smith 1896) com. nov. and Ralstonia eutropha (Davis 1969) comb. nov. Microbiol. Immunol., 39(11): 897-904 